\title{
Trace Metals Concentrations in Mangrove Sediments of Sepetiba Bay (Rio de Janeiro, Brazil): Microwave Assisted Digestion with Nitric Acid and Aqua Regia
}

\author{
Souza, P. S. A.; Marques, M. R. C.;* Soares, M. L. G.; Pérez, D. V. \\ Rev. Virtual Quim., 2012, 4 (4), 464-473. Data de publicação na Web: 18 de julho de 2012 \\ http://www.uff.br/rvq
}

\begin{abstract}
Concentrações de Metais Traço em Sedimentos de Manguezais da Baía de Sepetiba (Rio de Janeiro, Brasil): Digestão Assistida por Micro-ondas com Ácido Nítrico e Água Régia
\end{abstract}

Resumo: Sedimentos de manguezais têm uma grande capacidade em acumular metais traço que podem ser remobilizados e contaminar a água e a biota. Amostras de sedimentos foram coletadas em três florestas de mangue da Baía de Sepetiba (Itacuruçá, Coroa Grande e Guaratiba). Após a coleta foi efetuada a caracterização físico-química dos sedimentos $(\mathrm{pH}$, Eh, salinidade, composição granulométrica, carbono orgânico total-COT, $\mathrm{N}$ total e P-total) e as concentrações dos metais traço $(\mathrm{Cu}, \mathrm{Ni}, \mathrm{Pb}$ e $\mathrm{Zn})$ foram determinadas por dois diferentes protocolos de digestão ácida assistidos por micro-ondas $\left(\mathrm{HNO}_{3}\right.$ e $\left.\mathrm{HCl} / \mathrm{HNO}_{3}\right)$, que foram comparados, a fim de dar suporte à elaboração de uma futura legislação brasileira de avaliação da qualidade do sedimento. Os resultados mostraram que a escolha do método de digestão utilizado na avaliação da contaminação ambiental e no monitoramento de metais traço em sedimentos deve ser feita criteriosamente. Para isso, devem se levar conta as características físicas e químicas dos sedimentos, de forma a se evitarem erros de classificação de impactos ambientais.

Palavras-chave: Metais traço; contaminação; sedimentos.

\begin{abstract}
s
Mangrove sediments have a great capacity to accumulate trace metals that can be remobilized thus contaminating the water and biota. Concentrations of trace metals $(\mathrm{Cu}, \mathrm{Ni}, \mathrm{Pb}$ and $\mathrm{Zn})$ in mangrove sediment samples from Sepetiba Bay (Brazil) determined using two different protocols were compared, in order to give support for the establishment of a future legislation of environmental assessment of sediment quality in Brazil. Surface sediment samples were collected in three mangrove forests of Sepetiba Bay and were analyzed to determine $\mathrm{pH}$, Eh, salinity, and the percentages of sand, silt, clay, total organic carbon (TOC), total $\mathrm{N}$ and total $\mathrm{P}$. Concentrations of $\mathrm{Cu}, \mathrm{Ni}, \mathrm{Pb}$ and $\mathrm{Zn}$ were determined using two microwave acid digestion protocols, with two different agents: nitric acid $\left(\mathrm{HNO}_{3}\right)$ and aqua regia $\left(\mathrm{HCl} / \mathrm{HNO}_{3}\right)$. Results showed that the choice of the digestion method to use in the evaluation of environmental contamination and monitoring of trace metals in sediments should be made carefully, taking into account their physical and chemical characteristics in order to avoid misclassification of environmental impacts.
\end{abstract}

Keywords: Trace metals; contamination; sediments.

* Universidade do Estado do Rio de Janeiro, Laboratório de Tecnologia Ambiental, Instituto de Química, Rua São Francisco Xavier 524, Maracanã, CEP 20550-900, Tel.: +55(21)23340563, Rio de Janeiro, RJ, Brazil.

M monicamarques@ueri.br

DOI: $\underline{10.5935 / 1984-6835.20120035}$

Rev. Virtual Quim. |Vol 4| |No.4| |464-473| 


\title{
Trace Metals Concentrations in Mangrove Sediments of Sepetiba Bay (Rio de Janeiro, Brazil): Microwave Assisted Digestion with Nitric Acid and Aqua Regia
}

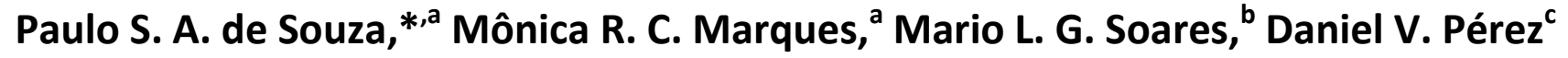

a Universidade do Estado do Rio de Janeiro, Laboratório de Tecnologia Ambiental, Instituto de Química, Rua São Francisco Xavier 524, Maracanã, CEP 20550-900, Rio de Janeiro, RJ, Brazil.

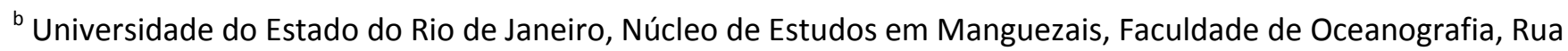
São Francisco Xavier, 524, Maracanã, CEP 20550-900, Rio de Janeiro, RJ, Brazil.

' Empresa Brasileira de Pesquisa Agropecuária, Centro Nacional de Pesquisa de Solos, Embrapa Solos, Rua Jardim Botânico 1024, Jardim Botânico, 22460-000 Rio de Janeiro, RJ, Brazil.

*monicamarques@uerj.br

Recebido em 6 de junho de 2012. Aceito para publicação em 8 de julho de 2012

\section{Introduction}

\section{Materials and methods}

2.1. Study area and sampling

2.2. Reagents and materials

2.3. Physicochemical characterization

2.4. Trace metals analysis

2.5. Statistical analysis

\section{Results and Discussion}

3.1. Field parameters and physicochemical characterization

3.2. Trace metals analysis

3.3. Statistical analysis

\section{Conclusions}

\section{Introduction}

Coastal areas encompass a broad range of saltwater ecosystems, including coral reefs, rocky shores, gravel shores, sandy shores, mudflats, sea grasses, marshes and mangrove forests. ${ }^{1}$ Urban and industrial activities located in these areas generate large volumes of wastewater that are finally discharged into marine ecosystems, affecting water and sediment quality. ${ }^{2}$

Mangrove forests exist where streams and rivers meet the sea and where tides and coastal currents mix. They are a rich source of commercial fishing and shellfish, and provide many recreational opportunities. ${ }^{3}$ During recent decades, mangrove ecosystems have been disappearing worldwide at the rate of $1 \%$ to $2 \%$ per year, a rate greater than or equal to those of threatened ecosystems like coral reefs and tropical rainforests. ${ }^{4,5}$

Due to their persistence, potential toxicity and bioavailability, trace metals represent a major threat to mangrove biodiversity and also to human health. ${ }^{6}$ Many complex geochemical processes, complicated 
by the great variability of major pore water parameters $(\mathrm{pH}$, redox, salinity), take place in mangrove sediments. These processes vary considerably due to seasonal and spatial variations. Moreover, reciprocal effects exist between plant species and sediment geochemistry. ${ }^{7,8}$ As a result, mangroves may act as a sink or a source of trace metals in tropical and subtropical coastal areas. ${ }^{2,9}$

To perform any monitoring on trace metal pollution it is necessary to find a method with the following requirements: be rapid, reproducible, inexpensive and able to quantify the degree of anthropogenic discharges. ${ }^{10}$ The majority of the techniques proposed for the analysis of trace metals in sediments deal with strong acid mixtures, which are able to release metals incorporated into the sediments from the water (non lattice held) and the ones which are part of the lattice structures of mineral components. ${ }^{11,12}$ For the assessment antropogenic metal pollution, the non lattice held fraction is of the prime interest instead of the total metal concentration. ${ }^{10}$ The analytical methodologies of sequential chemical extraction, in spite of allowing more comprehensive information on the distribution of physical chemistry and the availability of trace metals within the bulk sediment are complex, time consuming and are not suitable to be included in a routine monitoring program. ${ }^{10}$

Sample digestion is often a necessary step before determining metal concentrations. ${ }^{13}$ The introduction of microwave ovens, with both open and closed pressurized systems, has allowed a considerable reduction in the total time of analyses as well as in the risk of sample contamination. ${ }^{14}$ Whereas the use of closed digestion systems is mandatory for total determination of volatile elements, to avoid losses (e.g., As, $\mathrm{Se}, \mathrm{Hg}, \mathrm{Cr}$ ), the use of open systems allows higher sample intake and facilitates acid evaporation to dryness, hence reducing the subsequent analytical problems associated with high acid concentration. ${ }^{15,16}$

At present, there are various official methods which employ different acid mixtures and microwave heating systems (US-EPA 3050B, US-EPA 3051 and USEPA). ${ }^{17}$ Since the Environmental Protection Agency (EPA) has recommended the microwave-assisted method with nitric acid, this procedure to leach metals has been widely applied in sediment, soil and sludge samples. ${ }^{18}$ Nitric acid is strong enough to dissolve metals from fly ashes, from soils with organic carbon content up to $38 \%$, and from plant materials for environmental monitoring. ${ }^{19,20}$ Digestion with $\mathrm{HNO}_{3}$ extracts trace metals linked to material considered mobile in the environment, such as sulfides, hydroxides and some oxides. ${ }^{19}$ Around the Rev. Virtual Quim. |Vol 4| |No.4| |464-473| world, alternatively, many studies have evaluated the trace metal concentrations in sediments and soils using the aqua regia digestion procedure. ${ }^{17,21}$ The aqua regia $\left(3: 1, \mathrm{v} / \mathrm{v}, \mathrm{HCl}\right.$ to $\left.\mathrm{HNO}_{3}\right)$ digestion procedure is considered adequate for analyzing the totalrecoverable trace metals in soils and sediments, being efficient in extracting those metals associated with oxides, phosphates and sulfates. ${ }^{13,22}$ This digestion procedure is so widely used that the European Community Bureau of Reference has certified several soil and sediment samples based on it, in addition to the total elemental concentrations. ${ }^{23,24}$

Brazil still has no specific environmental legislation for the assessment of sediment. The applicable Brazilian rules, provided by Resolution 344/2004 from the National Environmental Council (CONAMA), classifies and regulates the disposal of dredged sediments. In this resolution, US-EPA 3051A (concentrated nitric acid digestion assisted by microwave) is the official protocol for the extraction of trace metals from sediments. ${ }^{25,26}$ This resolution also defines sediment quality criteria for trace metals and other contaminants, based on international experience (Level 1: threshold value below which there is low probability of adverse effects to biota and Level 2: threshold value above which adverse effects on the biota are expected). ${ }^{27,28}$

This study aimed to compare the concentrations of trace metals ( $\mathrm{Cu}, \mathrm{Ni}, \mathrm{Pb}$ and $\mathrm{Zn}$ ) in mangrove sediments from Sepetiba Bay (Brazil) obtained by two different microwave-assisted digestion methods, in order to confirm a metal contamination in the sea food chain and at the same time give support to the Brazilian State authorities to establish a future legislation of environmental assessment of sediment quality.

\section{Materials and methods}

\subsection{Study area and sampling}

Sepetiba Bay $\left(23^{\circ} 0^{\prime} 4^{\prime \prime} \mathrm{S}, 43^{\circ} 45^{\prime} 12^{\prime \prime} \mathrm{W}\right)$, with an area of $447 \mathrm{~km}^{2}$ and located about $60 \mathrm{~km}$ west of the city of Rio de Janeiro, is a body of brackish and saline waters that communicates with the Atlantic Ocean through two passages, one in the western part through a string of islands that borders on the edge of a sandbank, and the other in the eastern portion, through a channel that flows into Barra de Guaratiba. ${ }^{29}$ 
Its importance is unquestionable because it is a breeding place for various species in its extensive areas of mangroves and estuaries, and the fishing industry is an important economic and social support for the region. However, all these activities are threatened by the presence of an industrial complex composed of about 400 industries (including metallurgical, petrochemical and smelting companies, and also a leather tanning facility). These industries release large amounts of trace metals that reach the bay through the main rivers and by atmospheric deposition. ${ }^{30,31}$ Another important source of trace metals in Sepetiba Bay is the Santa Cruz Industrial District, with large export-oriented steel plants. A review of anthropogenic impacts in this area was presented by Molisani et al. (2004), ${ }^{30}$ which indicated $\mathrm{Zn}, \mathrm{Cd}, \mathrm{Pb}$, and $\mathrm{Hg}$ as the main metal contaminants. ${ }^{32}$

Surface sediment samples $(0-10 \mathrm{~cm})$ were collected in three regions of Sepetiba Bay (Figure 1).

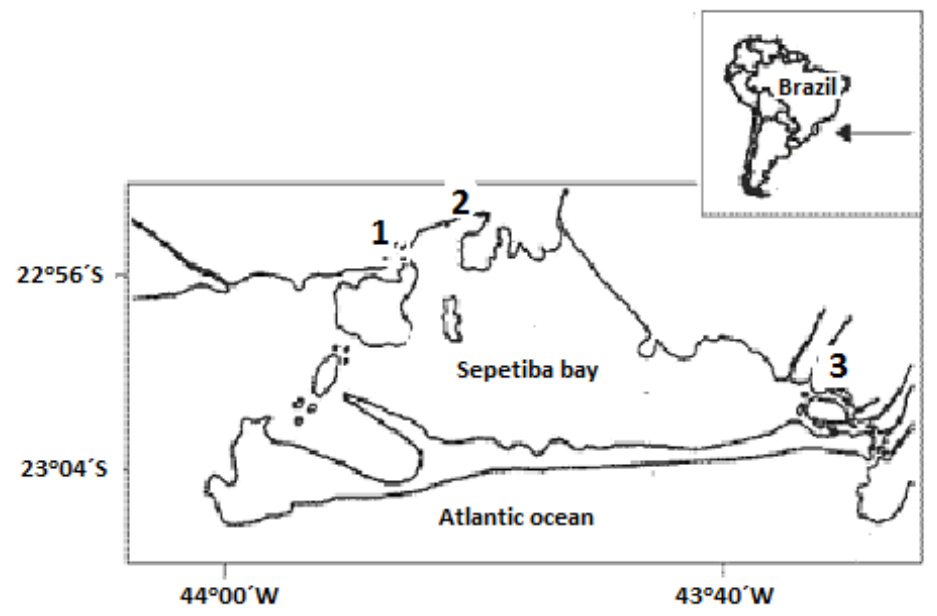

Figure 1. Study area and sampling regions

Region 1 is located in Itacuruçá mangrove marsh $\left(22^{\circ} 55^{\prime} 29.5^{\prime \prime} \mathrm{S}, 43^{\circ} 53^{\prime} 50^{\prime \prime} \mathrm{E}\right)$, Region 2 is located in Coroa Grande mangrove march $\left(22^{\circ} 54^{\prime} 13^{\prime \prime} \mathrm{S}\right.$, $\left.43^{\circ} 50^{\prime} 58^{\prime \prime} \mathrm{E}\right)$ and Region 3 is located in Guaratiba

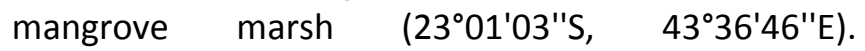
Collections were made at low tide, always in the region located in the intertidal zone, between the months of May and June 2010. In each region, five different samples were collected parallel to the shoreline, at a distance of approximately $10 \mathrm{~m}$. At the time of sample collection, measurements were made of $\mathrm{pH}$, Eh and temperature with a multiparameter analyzer (Hanna - HI 9828) and salinity was measured with a refractometer (Instrutemp - RTS-101 ATC). Samples were collected with plastic spoons, packed in sealed polyethylene plastic bags and kept under refrigeration with ice until arrival at the laboratory (about two hours), where they were frozen.

\subsection{Reagents and materials}

All glassware was washed with extran (5\% v/v), with $\mathrm{HNO}_{3}$ solution $1: 1(\mathrm{v} / \mathrm{v})$ and finally with deionized water. All solutions were prepared with "analytical grade" reagents (Merck or Sigma) and deionized water purified through the Milli-Q system (Millipore). The reference solutions to obtain the analytical curves for the determination of metals in sediment samples were prepared by serial dilution of stock solutions of $1000 \mathrm{mg} \mathrm{L}^{-1}$ (Qhemis) of $\mathrm{Pb}, \mathrm{Cu}, \mathrm{Ni}$ and $\mathrm{Zn}$ in $\mathrm{HNO}_{3} 1.0$ $\mathrm{mol} \mathrm{L}^{-1}$.

\subsection{Physicochemical characterization}

The sediment analysis followed the methodology from Embrapa (1999), ${ }^{33}$ as summarized below: samples were dried $\left(103-105^{\circ} \mathrm{C}\right)$, disaggregated and sieved through a $2 \mathrm{~mm}$ mesh. $\mathrm{pH}$ was measured with a potentiometer in a 1:2.5 soil/water suspension. Organic carbon was measured by oxidizing the organic material with potassium dichromate in an externally heated acidic medium and titration with ferrous ammonium sulfate. The particle size distribution thick sand $(2.00-0.20 \mathrm{~mm})$, fine sand $(0.20-0.05 \mathrm{~mm})$, silt $(0.05-0.02 \mathrm{~mm})$ and clay $(<0.002 \mathrm{~mm})$ - was determined by the densimeter method. Total nitrogen was determined by Kjeldahl steam distillation. Finally, 
the total phosphorus was determined by ICP-OES (Optima 3000 spectrometer from Perkin Elmer). ${ }^{34}$

\subsection{Trace metals analysis}

The trace metal concentrations were obtained by two different microwave-assisted digestion methods, using the extractants $\mathrm{HNO}_{3}$ and $\mathrm{HCl} / \mathrm{HNO}_{3}$.

$\mathrm{HNO}_{3}$ digestion: $0.50 \mathrm{~g}$ of sediment sample was weighed carefully into a Teflon digestion tube and 10 $\mathrm{cm}^{3}$ of concentrated $\mathrm{HNO}_{3}$ was added. Then the tubes were closed and the samples were heated in the microwave oven (Anton Paar - Multiwave 3000) (program: heating for $05: 30 \mathrm{~min}$ to $175^{\circ} \mathrm{C}$ and holding at $175^{\circ} \mathrm{C}$ for $\left.04: 30 \mathrm{~min}\right) .{ }^{19}$

$\mathrm{HCl} / \mathrm{HNO}_{3}$ digestion: $0,25 \mathrm{~g}$ of sediment sample was weighed carefully into a Teflon digestion tube and $2 \mathrm{~cm}^{3}$ of concentrated $\mathrm{HNO}_{3}$ and $6 \mathrm{~cm}^{3}$ of concentrated $\mathrm{HCl}$ were added, after which the tubes were closed and the samples were heated in the microwave oven (program: heating at 15:00 min to $140{ }^{\circ} \mathrm{C}$ and holding at $140{ }^{\circ} \mathrm{C}$ for $30 \mathrm{~min}$ ). ${ }^{35,36}$

To ensure the quality of the results obtained, blanks and two certified reference materials were analyzed in parallel together with the sediment samples: NIST-8704 (Buffalo River Sediment) which has certified values for the $\mathrm{HNO}_{3}$ method, and BCR$141 \mathrm{R}$ (Calcareous loam soil), which has certified values for the $\mathrm{HCl} / \mathrm{HNO}_{3}$ method.

After the digestions, the samples were filtered (Whatman $n^{\circ} 42$ filter), transferred to volumetric flasks and swollen to $50 \mathrm{~cm}^{3}$ with deionized water. The concentrations of trace metals were determined, in triplicates, using a flame atomic absorption spectrometer (Varian - ASA 240). The results obtained by both methods were compared with the sediment quality criteria for trace metals (Table 1) stipulated in CONAMA Resolution 344/2004. ${ }^{25}$

Table 1. Sediment Quality Guidelines stipulated in CONAMA Resolution 344/2004 (mg kg-1)

\begin{tabular}{ccc}
\hline Metal & ${\text { Level } \mathbf{1}^{\mathbf{a}}}$ & ${\text { Level } \mathbf{2}^{\mathbf{b}}}^{\mathbf{3}}$ \\
\hline $\mathbf{C u}$ & 34 & 270 \\
$\mathbf{N i}$ & 20.9 & 51.6 \\
$\mathbf{P b}$ & 46.7 & 218 \\
$\mathbf{Z n}$ & 150 & 410
\end{tabular}

a Threshold value below which there is a low probability of adverse effects on biota.

${ }^{b}$ Threshold value above which adverse effects on biota are expected

\subsection{Statistical analysis}

In coastal regions, several processes can affect each metal to different degrees because of intrinsic metal affinity for organic matter binding, clay adsorption and sensitivity to redox and $\mathrm{pH}$ conditions. Metal concentration in sediment depends on local environmental conditions and the distance from the main sources. Since these variables affect all metals, the study of metal distribution in sediments should ideally adopt a multivariate approach. ${ }^{29}$ In this study, multivariate analysis was performed using multiple linear regression (SSA for Windows; version: 9.1.3). The $\mathrm{HCl} / \mathrm{HNO}_{3}$ digestion method was defined as the dependent variable, with the independent variables being the $\mathrm{HNO}_{3}$ digestion method, $\mathrm{pH}$, organic carbon, sand content, silt content, Eh, nitrogen Kjeldahl and total phosphorus.

\section{Results and Discussion}

\subsection{Field parameters and physicochemical characterization}

The $\mathrm{pH}$ values obtained ranged from 6.61 to 8.37 (Table 2). According to Salomons et al. (1995), ${ }^{37}$ mangrove sediments have wide variation in $\mathrm{pH}$ values due to such factors as the effect of products of decomposition of organic matter and hydrolysis tannins, which produce various types of acids. 
Table 2. Field parameters and physicochemical characterization of sediment samples

\begin{tabular}{|c|c|c|c|}
\hline \multirow{2}{*}{ Parameters } & \multicolumn{3}{|c|}{ Sampling regions } \\
\hline & 1 & 2 & 3 \\
\hline $\mathrm{pH}^{\mathrm{a}}$ & 6,34 & 7,41 & 8,37 \\
\hline $\mathrm{Eh}(\mathrm{mV})^{\mathrm{a}}$ & $+135,6$ & $+168,8$ & $-210,4$ \\
\hline Temperature $\left({ }^{\circ} \mathrm{C}\right)^{\mathrm{a}}$ & 21,4 & 22,1 & 25.3 \\
\hline Salinity $\%{ }^{a}$ & 30 & 25 & 42 \\
\hline Organic matter $\left(\mathrm{g} \mathrm{Kg}^{-1}\right)^{\mathrm{b}}$ & 12,90 & 31,20 & 107,1 \\
\hline Nitrogen Kjeldhal $\left(\mathrm{mg} \mathrm{Kg}^{-1}\right)^{\mathrm{b}}$ & 760 & 2.000 & 7.140 \\
\hline Total-P $\left(\mathrm{mg} \mathrm{Kg}^{-1}\right)^{\mathrm{b}}$ & 180 & 370 & 2.050 \\
\hline
\end{tabular}

Region 1: Itacuruçá; Region 2: Coroa Grande, Region 3: Guaratiba.

${ }^{a}$ Measured in one point of each region; ${ }^{b}$ Averages of the five points in each region

The Eh measurements obtained (Table 2) indicated that the sediments in Region 3 ( $E \mathrm{~h}=-210.4 \mathrm{mV}$ ) have anoxic conditions (sulfate reduction) and the characteristics of Region 2 (Eh $=+168.8 \mathrm{mV}$ ) and Region 1 (Eh $=+135,6 \mathrm{mV}$ ) are subtoxic (lacks measurable oxygen or sulfide, but contains dissolved iron or manganese, no reduction of sulfate). This discrepancy is due to seasonal variations in tidal range and the different seasons (influence on the input of organic matter, mainland sediments in runoff, etc.). ${ }^{8}$

$x$ The salinity values (Table 2 ) obtained ranged from 25 to $42 \mathrm{~g} \mathrm{~kg}^{-1}$. This variation may be due to the presence of fresh water from rivers, seasons (dry and rainy) and tides. ${ }^{26}$

Mangrove environments are naturally enriched with nutrients like $\mathrm{N}$ and $\mathrm{P}$, which are present in organic and inorganic forms and are cycled in the environment through biogeochemical cycles. The results indicated that the Region 3 showed the highest levels of total nitrogen and total phosphorus (Table 2). This is possibly due to the fact that this point is located in Guaratiba mangrove marsh, which is located in the Guaratiba Biological and Archaeological Reserve. It is an extensive area of mangroves, covering 2800 ha, which is the main area in biological productivity of Sepetiba Bay. ${ }^{8}$

Due to particle size (Table 3 ), in Regions 1 and 2 the sand fraction is predominant and in Region 3 the total silt and clay fractions are predominant. The results obtained for the granulometric compositions agree with those obtained for organic matter content (Table 2) in Region 3. This region had the highest clay content $\left(480 \mathrm{~g} \mathrm{~kg}^{-1}\right)$ and hence high organic matter adsorption capacity. ${ }^{39}$

Table 3. Particle size distribution of sediment samples

\begin{tabular}{lccc}
\hline \multirow{2}{*}{ Particle size distribution } & \multicolumn{3}{c}{ Sampling regions $\mathbf{( \mathbf { ~ K g } ^ { - \mathbf { 1 } } \mathbf { ~ }}$} \\
\cline { 2 - 4 } & $\mathbf{1}$ & $\mathbf{2}$ & $\mathbf{3}$ \\
\hline Thick sand & 574 & 518 & 72 \\
Fine sand & 276 & 226 & 56 \\
Silt & 90 & 116 & 392 \\
Clay & 60 & 140 & 480 \\
\hline
\end{tabular}

\subsection{Trace metals analysis}

Table 4 presents the results of the recovery rates obtained for $\mathrm{Cu}, \mathrm{Ni}, \mathrm{Pb}$ and $\mathrm{Zn}$ in the certified reference materials NIST-8704 and BCR-141R (calcareous loam soil).

The recovery rates were between 90 and 106\%, within the recommended range of 75 to $125 \% .{ }^{19}$
The copper concentrations (Figure 2) obtained by the two methods showed no significant differences in the three sampling regions.

On the other hand, the concentrations of $\mathrm{Ni}$ (Figure 3), $\mathrm{Pb}$ (Figure 4) and $\mathrm{Zn}$ (Figure 5) in Region 3 obtained with the $\mathrm{HCl} / \mathrm{HNO}_{3}$ digestion method $\left(39.8 \pm 1.5 ; 64.6 \pm 0.7\right.$ and $610.0 \pm 22.0 \mathrm{mg} \mathrm{kg}^{-1}$, respectively) were much higher than those obtained only with the $\mathrm{HNO}_{3}$ digestion method (22.5 \pm 0.9 ; $46.9 \pm 1.2$ and $387.0 \pm 15.0 \mathrm{mg} \mathrm{kg}^{-1}$, respectively). 
Table 4. Recovery rates of trace metals in reference materials NIST-8704 and BCR-141R

\begin{tabular}{|c|c|c|c|c|}
\hline \multirow{2}{*}{$\begin{array}{c}\text { NIST } 8704 \\
\left(\mathrm{HNO}_{3}\right)^{*}\end{array}$} & \multicolumn{4}{|c|}{ Metal Concentration $\left(\mathrm{mg} \mathrm{Kg}^{-1}\right)$} \\
\hline & $\mathrm{Cu}$ & $\mathbf{N i}$ & $\mathrm{Pb}$ & $\mathrm{Zn}$ \\
\hline Obtained Value & $85 \pm 6$ & $43 \pm 3$ & $153 \pm 14$ & $424 \pm 20$ \\
\hline Certified Value & $\mathrm{NC}$ & $43 \pm 4$ & $150 \pm 17$ & $408 \pm 15$ \\
\hline \% Recovery & NC & 101 & 102 & 104 \\
\hline BCR 141R & \multicolumn{4}{|c|}{ Metal Concentration $\left(\mathrm{mg} \mathrm{Kg}^{-1}\right)$} \\
\hline$\left(\mathrm{HNO}_{3} / \mathrm{HCl}\right)^{*}$ & $\mathrm{Cu}$ & $\mathbf{N i}$ & $\mathrm{Pb}$ & $\mathrm{Zn}$ \\
\hline Obtained Value & $42 \pm 3$ & $99 \pm 5$ & $53 \pm 28$ & $273 \pm 9$ \\
\hline Certified Value & $47 \pm 2$ & $94 \pm 5$ & $51 \pm 2.0$ & $270 \pm 8$ \\
\hline \% Recovery & 90 & 106 & 104 & 101 \\
\hline
\end{tabular}

*Extracting agent used in microwave-assisted digestion. NC: not certified

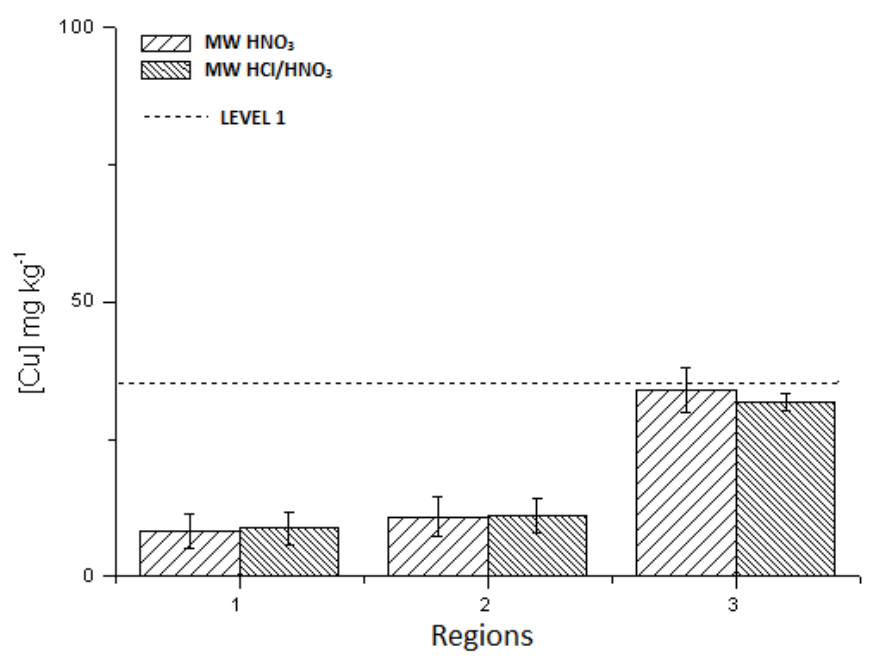

Figure 2. Cu concentrations obtained with microwave (MW) $\mathrm{HNO}_{3}$ and microwave (MW) $\mathrm{HCl} / \mathrm{HNO}_{3}$ methods in each sampling region

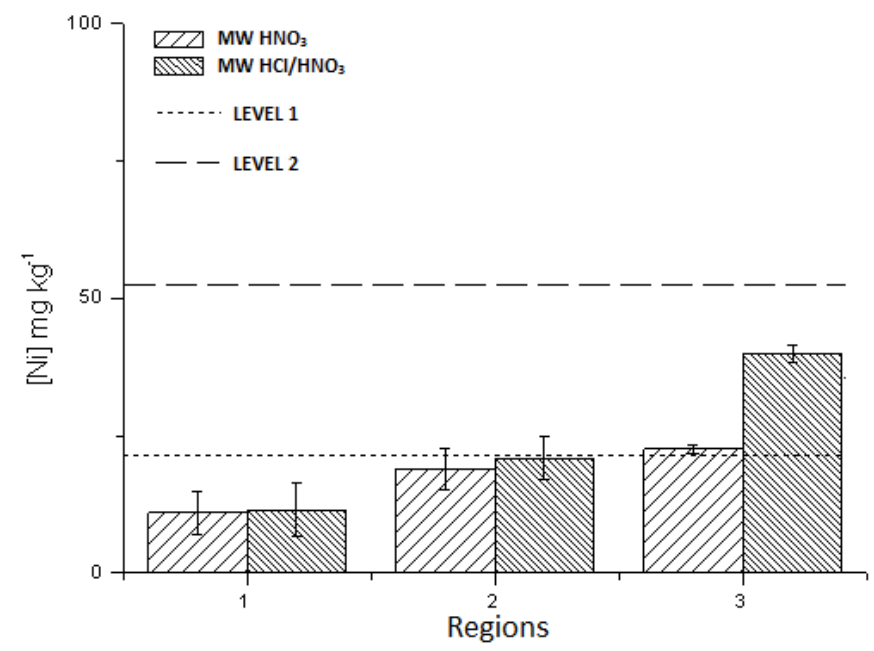

Figure 3. Ni concentrations obtained with microwave $(\mathrm{MW}) \mathrm{HNO}_{3}$ and microwave $(\mathrm{MW}) \mathrm{HCl} / \mathrm{HNO}_{3}$ methods in each sampling region 


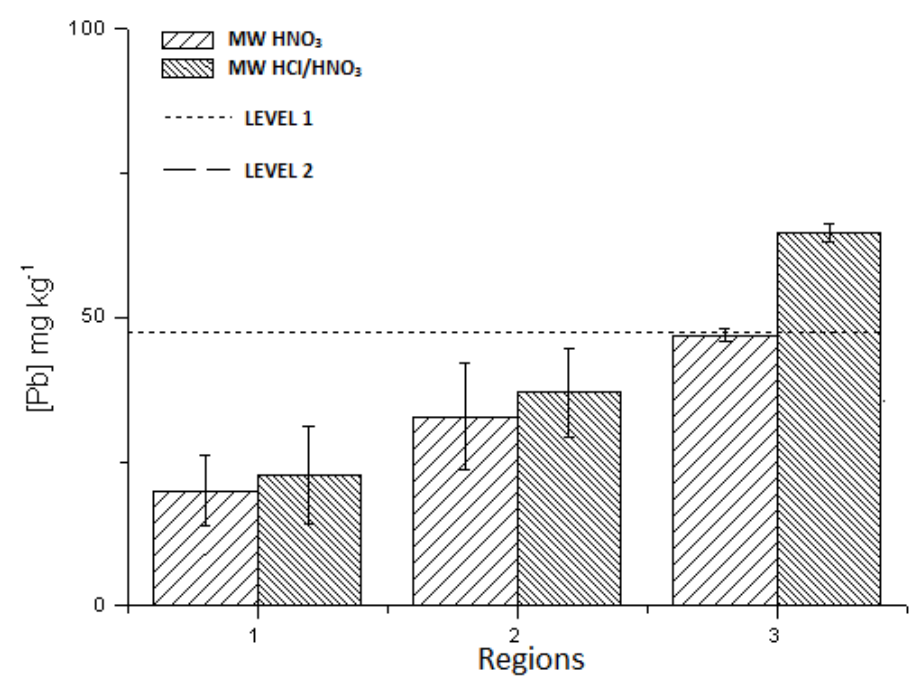

Figure 4. $\mathrm{Pb}$ concentrations obtained with microwave $(\mathrm{MW}) \mathrm{HNO}_{3}$ and microwave $(\mathrm{MW}) \mathrm{HCl} / \mathrm{HNO}_{3}$ methods in each sampling region

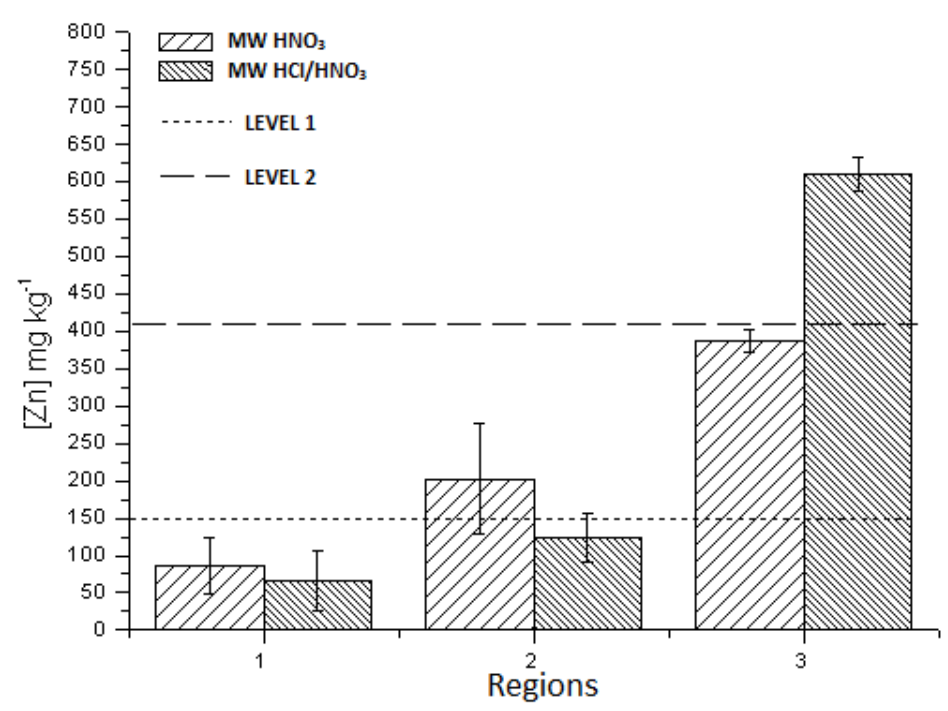

Figure 5. $\mathrm{Zn}$ concentrations obtained with microwave (MW) $\mathrm{HNO}_{3}$ and microwave (MW) $\mathrm{HCl} / \mathrm{HNO}_{3}$ methods in each sampling region

The high organic matter content, silt and clay dominant particle size and the low redox potential (Table 2) favor adsorption and complexation of these metals in this region's sediments. ${ }^{40,41}$ Furthermore, the high content of total phosphorus $\left(2.050 \mathrm{mg} \mathrm{kg}^{-1}\right)$ in Guaratiba sediments suggests the presence of these metals associated with phosphates, which favors its dissolution in aqua regia $\left(\mathrm{HCl} / \mathrm{HNO}_{3}\right){ }^{22}$ In Itacuruçá (Region 1) and Coroa Grande (Region 2), the concentrations of $\mathrm{Ni}, \mathrm{Pb}$ and $\mathrm{Zn}$ obtained by the two extracting agents (Table 5) showed no significant differences, indicating that both methods can be used for these metals in sediments with predominance of sand fraction and low organic matter.

The results obtained also show that the mangrove in the most critical situation is Guaratiba.
Concentrations above "level 1" and below "level 2" (Table 1) for the metals $\mathrm{Ni}$ and $\mathrm{Pb}$ were obtained using the two digestion methods (Figures 2, 3, 4 and 5). For $\mathrm{Zn}$, the classification obtained was above "level 2" using the $\mathrm{HCl} / \mathrm{HNO}_{3}$ method.

\subsection{Statistical analysis}

Table 5 shows the values of partial determination coefficients $(r)$ and determination coefficients $\left(R^{2}\right)$ obtained by the introduction of the independent variables that were statistically significant $(p=0.05)$ in the multiple linear regression model for each trace metal evaluated. 
Table 5. Multiple linear regression results $(p=0.05)$

\begin{tabular}{ccccc}
\hline Metal & $\begin{array}{c}\text { Independent } \\
\text { variable added }\end{array}$ & $\begin{array}{c}\text { Number of independent } \\
\text { variables }\end{array}$ & $\boldsymbol{r}$ & $\mathbf{R}^{\mathbf{2}}$ \\
\hline $\mathrm{Cu}$ & $\mathrm{HNO}_{3}{ }^{*}$ & 1 & - & 0.97 \\
\hline \multirow{2}{*}{$\mathrm{Ni}$} & $\mathrm{HNO}_{3}{ }^{*}$ & 1 & - & 0.74 \\
& $\mathrm{Sand}$ & 2 & 0.24 & 0.98 \\
& $\mathrm{P}$-total & 3 & 0.008 & 0.99 \\
\hline $\mathrm{Pb}$ & $\mathrm{HNO}_{3}{ }^{*}$ & 1 & - & 0.90 \\
& $\mathrm{P}$-total & 2 & 0.064 & 0.96 \\
\hline $\mathrm{Zn}$ & $\mathrm{HNO}_{3}{ }^{*}$ & 1 & - & 0.84 \\
& $\mathrm{P}$-total & 2 & 0.13 & 0.97 \\
\hline
\end{tabular}

*Defined as the independent variable set by the model. $r$ : partial determination coefficient. $\mathrm{R}^{2}$ : determination coefficient

In relation to $\mathrm{Cu}$, any parameter caused significant improvement in the multiple regression model for the relationship between the two acid digestion methods. The sand parameter caused the most significant improvement $(r=0.24)$ in the relationship between the two methods for $\mathrm{Ni}$, with the coefficient of determination $\left(R^{2}\right)$ increasing from 0.69 to 0.98 . This may indicate that in sediments dominated by sand fraction, extraction by $\mathrm{Ni} \mathrm{HCl} / \mathrm{HNO}_{3}$ digestion is more efficient than that with $\mathrm{HNO}_{3}$. For the elements $\mathrm{Pb}$ and $\mathrm{Zn}$, the inclusion of the parameter P-total as independent variable caused the greatest improvement in the coefficients of determination. This corroborates the results shown above (Table 2 and Figures 2, 3, 4 and 5), where it was found that in sediments with higher concentrations of P-total, the concentrations of $\mathrm{Pb}$ and $\mathrm{Zn}$ obtained with the $\mathrm{HCl} / \mathrm{HNO}_{3}$ method were significantly higher than with digestion by the $\mathrm{HNO}_{3}$ method.

\section{Conclusions}

Both methods of acid digestion assisted by microwave heating produce similar results for $\mathrm{Cu}$, regardless of the physicochemical characteristics of the sediments.

The $\mathrm{HCl} / \mathrm{HNO}_{3}$ method has higher extraction capacity than the $\mathrm{HNO}_{3}$ method for $\mathrm{Ni}, \mathrm{Pb}$ and $\mathrm{Zn}$ in sediments dominated by silt and clay with high organic matter content and total-P.

The choice of the digestion method to use in the evaluation of environmental contamination and monitoring of trace metals in sediments should be made carefully, taking into account their physical and chemical characteristics in order to avoid misclassification of environmental impacts.
It should be noted also that the high concentrations of trace metals found in Guaratiba, which is a biological reserve, demonstrate the vulnerability of a protected area against remote agents as the sources of trace metals in Sepetiba Bay.

\section{References}

${ }^{1}$ Sítio do National Centers for Coastal Ocean Science (NOOA). Disponível em: $<$ http://www.nccos.noaa.gov>. Acesso em: 17 agosto 2010.

2 Froehner, S.; Machado, K. S.; Stefen E.; Nolasco, M. Water Air Soil Pollut. 2011, 219, 591. [CrossRef]

${ }^{3}$ Sharpe, M. J. J. Environ Monit. 2005, 7, 401. [CrossRef] [PubMed]

${ }^{4}$ Sítio da Food and Agriculture Organization of the United Nations (FAO). Disponivel em: $<$ http://www.fao.org/docrep/007/j1533e/J1533E00.h tm>. Acesso em: 15 março 2010.

${ }^{5}$ Duke, N. C.; Meynecke, J. O.; Dittmann, S.; Ellison, A.; Anger, K.; Berger, U.; Cannicci, S.; Diele, K.; Ewel, K. C.; Field, C. D.; Koedam, N.; Lee, S. Y.; Marchand, C.; Nordhaus, I.; Smith, T. J. III; Dahdouh-Guebas, F. Science $2007,317,41$. [CrossRef] [PubMed]

${ }^{6}$ Marchand, C.; Lallier-Vergès, E.; Allenbach, M. J. Soils Sediments 2011, 11, 529. [CrossRef]

${ }^{7}$ McKee, K. L. J. Ecol. 1993, 81, 477. [CrossRef]

8 Marchand, C.; Baltzer, F.; Lallier-Vergès, E.; Albéric, P. Mar. Geol. 2004, 208, 361. [CrossRef]

${ }^{9}$ Tam, N. F. Y.; Wong, Y. S. Environ. Pollut. 2000, 110, 195. [CrossRef]

${ }^{10}$ Fiszman, M.; Pfeiffer, W. C.; Lacerda, L. D. Environ. 
Tech. Lett. 1984, 5, 567. [CrossRef]

${ }^{11}$ Bloom, H.; Ayling, G. M. Environ. Geol. 1977, 2, 3. [CrossRef]

12 Mayerson, A. L.; Luther III, G. W.; Krajeruski, J.; Hires, R. I. Mar. Pollut. Bull. 1981, 12, 243. [CrossRef]

${ }^{13}$ Sakan, S.; Dordevic, D.; Devic, G.; Relic, D.; Andelkovic, I.; Duricic, J. Microchem. J. 2011, 99, 492. [CrossRef]

${ }^{14}$ Jin, Q.; Liang, F.; Zhang, H.; Zhao, L.; Huan, Y.; Song, D. Trends Anal. Chem. 1999, 18, 479. [CrossRef]

${ }^{15}$ Smith, F. E.; Arsenault, E. A. Talanta 1996, 43, 1207. [CrossRef]

${ }^{16}$ Nakashima, S.; Sturgeon, R. E.; Willie, S. N.; Berman, S. S. Analyst. 1998, 113, 159. [CrossRef]

${ }^{17}$ Bettinelli, M.; Beone, G. M.; Spezia, S.; Baffi, C. Anal. Chim. Acta 2000, 424, 289. [CrossRef]

${ }^{18}$ Rönkkömäki, H.; Pöykio, R.; Nurmesniemi, H.; Popov, K.; Merisalu, E.; Tuomi, T.; Välimäki, I. J. Environ. Sci. Tech. 2008, 5, 485. [Link]

${ }^{19}$ Sítio da United States Environmental Protection Agency (USEPA). Disponível em: <http://www.epa.gov/wastes/hazard/testmethods/s w846/pdfs/6010c.pdf $>$. Acesso em: 18 abril 2010.

${ }^{20}$ Chen, M.; Ma, L. Q. J. Environ. Qual. 1998, 27, 1294. [CrossRef]

${ }^{21}$ Relić, D.; Đorđević, D.; Sakan, S.; Anđelković, I.; Miletić, S.; Đuričić, J. J. Hazard Mater. 2011, 186, 1893. [PubMed]

${ }^{22}$ Nieuwenhuize, J.; Poley-Vos, C. H.; Akker, A. H.; Delft, W. V. Analyst 1991, 116, 347. [CrossRef]

${ }^{23}$ Vercoutere, K.; Fortunati, U.; Muntau, H.; Griepink, B.; Maier, E. A. J. Anal. Chem. 1995, 352, 197. [CrossRef]

${ }^{24}$ Quevauviller, P.; Imbert, J.; Olle, M. Microchim. Acta. 1993, 112 , 147. [CrossRef]

${ }^{25}$ Sítio do Ministério do Meio Ambiente (Brasil). Disponível em: <http://www.mma.gov.br/port/conama/res/res04/re s34404.xml>. Acesso em: 15 Junho 2010.

${ }^{26}$ Cotta, J. A. O.; Rezende, M. O. O. ; Piovani, M. R. Quim. Nova. 2006, 29, 40. [CrossRef]

${ }^{27}$ Pereira, J. C.; Guimaraes-Silva, A. K.; Nalini Jr., H. A.; Pacheco-Silva, E.; Lena, J. C. Quim. Nova. 2007, 5, 1249. [CrossRef]

${ }^{28}$ Sítio do Canadian Sediment Quality Guidelines for the Protection of Aquatic Life (CCME). Disponível em: 473
<http://www.ecy.wa.gov/programs/eap/psamp/Boun daryBay/PSAMPBBAMP\%20documents/Canadian $\% 20$ guidelines\%20for\%20water\%20quality/SedimentProt AquaticLifeSummaryTables(en).pdf>. Acesso em: 29 Julho 2010.

${ }^{29}$ Bailey, T. C.; Barcellos, C.; Krzanowski, W. J. Environmetrics 2005, 16, 563. [CrossRef]

${ }^{30}$ Molisani, M. M.; Marins, R. V.; Machado, W.; Paraquetti, H. H. M.; Bidone, E. D.; Lacerda, L. D. Environ. Change. 2004, 4, 17. [CrossRef]

${ }^{31}$ Gomes, F. C.; Godoy, J. M.; Godoy, M. L.; Carvalho, Z. L.; Lopes, R. T.; Sanchez-Cabeza, J. A. Mar. Pollut. Bull. 2009, 59, 123. [CrossRef]

${ }^{32}$ Machado, E. C.; Machado, W.; Bellido, L. F.; Patchineelam, S. R.; Bellido, A. V. B. Water Air Soil Pollut. 2008, 192, 77. [CrossRef]

${ }^{33}$ Embrapa (Empresa Brasileira de Pesquisa Agropecuária); Manual de Métodos de Análise de Solo, Serviço Nacional de Levantamento e Conservação de solos: Rio de Janeiro, 1999.

${ }^{34}$ Mudroch, A.; Azcue, J. M.; Mudroch, P.; Manual of physical-chemical analyses of aquatic sediments, Lewis Publishers: Boca Raton, 1995.

${ }^{35}$ Kisser, M. I., Digestion of solid matrices - Part 1: Digestion with aqua regia - Report of evaluation study. Disponível em: $<$ http://www.ecn.nl/docs/society/horizontal/Digestio $\mathrm{n}$ report Aqua regia.pdf $>$. Acesso em: 01 agosto 2011.

${ }^{36}$ Melaku, S.; Damn, M. L. Anal. Chim. Acta 2005, 543, 117. [CrossRef]

${ }^{37}$ Salomons, W.; Stigliani, W. M.; Biogeodynamics of pollutants in soils and sediments: Risk assessement of delayed and non linear responses, Springer: Berlin, 1995.

${ }^{38}$ Cardoso, A. G. A.; Boaventura, G. R.; Silva-Filho, E. V.; Brod, J. A. J. Braz. Chem. Soc. 2001, 12, 767. [CrossRef]

${ }^{39}$ Sítio do Projeto Manguezais da Empresa Brasileira de Pesquisa Agropecuária. Disponível em: $<$ http://www.cnpma.embrapa.br/site projeto mangu ezais/importancia.htm>. Acesso em: 16 agosto 2010.

${ }^{40}$ Clark, M. W.; Mc Conchie, D.; Lewis, D. W.; Saenger, P. Chem. Geol. 1998 , 149, 147. [CrossRef]

${ }^{41}$ Lacerda, L. D.; Trace metals biogeochemistry and difuse pollution in mangrove ecosystems, International society for mangrove ecosystems: Okinawa, 1998.

Rev. Virtual Quim. |Vol 4| |No.4| |464-473| 